\title{
DROPLETS FROM THE PLANKTON NET XXIV. THE PREDOMINANT TYPE OF VELELLA IN JAPANESE WATERS
}

$\operatorname{AUTHOR}(S)$ :

Bieri, Robert

\section{CITATION:}

Bieri, Robert. DROPLETS FROM THE PLANKTON NET XXIV. THE PREDOMINANT TYPE OF VELELLA IN JAPANESE WATERS. PUBLICATIONS OF THE SETO MARINE BIOLOGICAL LABORATORY 1970, 17(5): 303-304

\section{ISSUE DATE:}

1970-02-21

URL:

http://hdl.handle.net/2433/175608

RIGHT: 


\title{
DROPLETS FROM THE PLANKTON NET XXIV. THE PREDOMINANT TYPE OF VELELLA IN JAPANESE W ATERS ${ }^{1)}$
}

\author{
ROBERT BIERI
}

Antioch College, Yellow Springs, Ohio 45387

\section{With 1 Table}

The appearance of Katsuonokanmuri or bonito's crown along the coast of Japan heralds the approach of warm water and good fishing for bonito. How fine that Velella, bringing such good news, also adds only beauty to the sea scape-no poisonous stings!

From November 1965 to June 1966, I recorded the occurrence of Velella along the beaches of Shirahama. A summary of my data is given in Table 1. Velella

Table 1. Records of Velella strandings, Shirahama

\begin{tabular}{llcr}
\hline \multicolumn{1}{c}{ Date } & Type & Number & Size Range mm \\
\hline Nov. 5, 1965 & Left & 5 & $12-25$ \\
Nov. 8, 1965 & Left & 15 & $9-30$ \\
Nov. 9, 1965 & Left & 31 & $9-38$ \\
& Right & 6 & $3-18$ \\
Mar. 4, 1966 & Left & 230 & $5.5-50$ \\
Mar. 5, 1966 & Left & 51 & $15-58$ \\
Mar. 23-24, 1966 & Left & 70 & $14-36$ \\
April 27, 1966 & Right & 1 & 22 \\
& Left & 283 & $7-62$ \\
June 8, 1966 & Right & 80 & $17-61$ \\
& Left & 5 & $16-29$ \\
\hline
\end{tabular}

Total: Left 690, Right 87

was stranded only nine days out of 230 . In all, with the generous help of Mr. $\mathrm{H}$. TANASE and some sailors of the glass bottom boats, I collected 777 specimens of Velella. Six-hundred ninety or $90 \%$ of them were left handed; that is, if the animal is held with the long axis north and south the crest runs from northwest to southeast. The remainder were right handed. In Velella, left handers sail to the left of the wind.

1) Contributions from the Seto Marine Biological Laboratory, No. 515.

Publ. Seto Mar. Biol. Lab., XVII (5), 303-304, 1970. (Article 18) 
Thus the theory of SAvilov (1958-1961) is upheld. Left handed Velella sailing to the left of the wind should be most abundant along the outer edges of the clock-wise rotating wind and current system. The right-handers should be most abundant inside such a gyre. But winds and currents are variable with many eddies; so it is to be expected that nature does not perfectly fulfill our theories. In this case, she contradicts our predictions $10 \%$ of the time.

\section{REFERENCES}

SAvilov, A.I. 1958. Pleuston of the Western Part of the Pacific Ocean. Doklady Akad. Nauk SSSR, Vol. 122, No. 6, pp. 1010-1017. (in Russian)

1961. The Distribution of the Ecological Forms of the By-the-Wind-Sailor, Velella lata Crr. and Eys., and the Portuguese Man-of-War, Physalia utriculus (LA MArtinierr) Esch., in the North Pacific. Trudy Inst. Okeanol. Akad. Nauk SSSR, Vol. 45, pp. 223-239. (in Russian) 